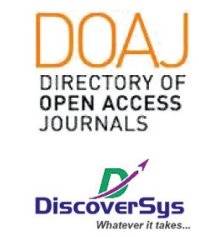

Published by DiscoverSys

\section{Profil dermatitis seboroik pada pasien di Poliklinik Rawat Jalan Kulit dan Kelamin RSUD Wangaya Denpasar periode Oktober 2017-Oktober 2018}

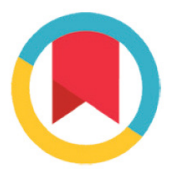

CrossMark

\author{
Elisia ${ }^{1 *}$, Tjokorda Dalem Pemayun ${ }^{1}$
}

\begin{abstract}
Introduction: Seborrheic dermatitis is a chronic superficial skin disorder occurs in 2-5\% of population with the symptom of erythematous plaque with slightly yellowish scaling and without clear border, it caused by multifactorial etiopathogenesis includes sebaceous gland secretion, Malassezia fungi colonization, and immune response. This disease is higher in rich sebaceous gland area, is mostly found in the face, upper trunk, and intertriginous (inguinal, inframammary, and axilla).

Aim: This study aimed to know the profile of seborrheic dermatitis patients in dermatovenereology outpatient clinic of Wangaya General Hospital in October 2017-0ctober 2018 period. Methods: This study is a retrospective study based on the number of cases, sex, age group, location of lesion, and type of treatment from
\end{abstract}

patient medical records of dermatovenereology outpatient clinic in Wangaya General Hospital in 2017-2018 period.

Results: Seborrheic dermatitis mostly found in men $(64,2 \%)$ with the adult age group is the highest number $(77,6 \%)$. This disease often affected the face area in 36 patients $(53,7 \%)$. The most frequent treatment used was anti-inflammation agent in 41 samples (61,2\%). In this study, anti-inflammation used were topical corticosteroids $(64,2 \%)$, there were betamethasone for adults and hydrocortisone for children.

Conclusion: Seborrheic dermatitis were mostly found in male, occurred in the age group $\geq 35$ years. The location of lesion is higher found in face area and mostly treated with corticosteroid.

Keywords: Bali, dermatitis, seborrheic, Wangaya, dermatovenereology

Cite This Article: Elisia, Pemayun, T.D. 2019. Profil dermatitis seboroik pada pasien di Poliklinik Rawat Jalan Kulit dan Kelamin RSUD Wangaya Denpasar periode Oktober 2017-Oktober 2018. Intisari Sains Medis 10 (2): 497-500. D0I: 10.15562/ism.v10i2.414

'Bagian/SMF IImu Kesehatan Kulit dan Kelamin, Rumah Sakit Umum Daerah Wangaya Denpasar, Bali

*Korespondensi :

Elisia; Bagian/SMF IImu Kesehatan Kulit dan Kelamin, Rumah Sakit Umum Daerah Wangaya Denpasar, Bali;

92elisia@gmail.com

\section{ABSTRAK}

Pendahuluan: Dermatitis seboroik merupakan penyakit kulit kronis superfisial yang menyerang 2-5\% populasi dengan gejala berupa lesi berbentuk plak eritematosa dengan skuama berminyak kekuningan berbatas tidak tegas yang disebabkan oleh berbagai faktor termasuk berhubungan dengan sekresi kelenjar sebasea, kolonisasi jamur Malassezia, dan respon imun. Penyakit ini banyak didapati pada daerah yang kaya akan kelenjar sebasea yaitu daerah wajah, badan bagian atas, lipatan tubuh termasuk inguinal, inframama, dan aksila.

Tujuan: Penelitian ini bertujuan untuk mengetahui profil pola penyakit dermatitis seboroik pada pasien di poliklinik Kulit dan kelamin RSUD Wangaya periode Oktober 2017-0ktober 2018. Metode: Penelitian dilakukan secara retrospektif pada pasien dermatitis seboroik berdasarkan jumlah kasus, jenis kelamin, kelompok umur, lokasi lesi, dan pilihan terapi dengan mengambil data catatan kunjungan pasien poliklinik Kulit dan Kelamin RSUD Wangaya tahun 2017-2018.

Hasil: Jumlah pasien dermatitis seboroik tercatat sebanyak 67 pasien (2,3\%). Dermatitis seboroik lebih sering ditemui pada laki-laki sebanyak $64,2 \%$ dengan usia terbanyak adalah dewasa $\geq 35$ tahun sejumlah 52 pasien $(77,6 \%)$. Penyakit ini seringkali menyerang daerah wajah sebanyak 36 pasien (53,7\%). Terapi terbanyak yang diberikan yaitu anti inflamasi sebanyak 41 pasien (61,2\%). Pada penelitian ini, anti inflamasi yang seringkali digunakan adalah kortikosteroid topikal $(64,2 \%)$, yaitu betametason untuk dewasa dan hidrokortison untuk anak.

Kesimpulan: Dermatitis seboroik paling banyak menyerang laki-laki usia dewasa $\geq 35$ tahun. Lokasi tersering yang ditemui adalah wajah dengan terapi yang terbanyak diberikan adalah kortikosteroid. 


\section{PENDAHULUAN}

Dermatitis seboroik menyerang $1-5 \%$ populasi dunia, di Asia sendiri bervariasi antara 2,1\% di Korea Selatan sampai $26,5 \%$ di Indonesia. Data dari Kemenkes menyebutkan pasien dermatitis seboroik di poliklinik kulit dan kelamin di berbagai rumah sakit di Indonesia pada tahun 2013-2015 adalah 0,99\%-5,8\%. ${ }^{1}$ Sedangkan jumlah pasien di poliklinik kulit dan kelamin RSUP Sanglah Bali sendiri tercatat $1,03 \%$ dari keseluruhan pasien. ${ }^{2}$

Insidensi Dermatitis Seboroik sendiri tersering pada usia 3 bulan pertama sampai usia 3 tahun, selama pubertas, dan pada usia dewasa sekitar 4060 tahun. Laki-laki lebih sering terkena penyakit ini dibandingkan perempuan dengan perbandingan $3 \%$ banding 2,6\% di semua kelompok usia. Pada bayi usia 3 bulan, dermatitis seboroik ini umumnya menyerang bagian kulit kepala, wajah, dan pantat. Sedangkan pada remaja dan dewasa banyak ditemukan pada wajah, dada, ketiak, dan lipatan inguinal. $^{3}$

Dermatitis seboroik merupakan penyakit inflamasi kronis yang umum pada kulit dengan manifestasi berupa plak eritematosa dengan skuama putih kering atau kuning berminyak yang cukup gatal pada daerah sebasea yaitu pada kulit kepala, wajah termasuk alis, bulu mata, dan area janggut. Penyakit ini juga seringkali menyerang daerah lipatan tubuh seperti aksila, lipatan payudara, lipatan paha, serta area anogenital.

Penyebaran dermatitis ini biasanya simetris dan bervariasi mulai dari ringan, membentuk plak berskuama sampai membentuk krusta lengket yang tebal. Lesi pada lipatan tubuh bisa tampak merah, halus, dan kadang tampak mengkilat. ${ }^{4}$

Penyebab pasti dari infeksi ini belum diketahui namun ada beberapa faktor yang mempengaruhi etiopatogenesis antara lain sekresi kelenjar sebasea yang berlebihan, kolonisasi Malassezia spp., dan respon imun tubuh penderita. ${ }^{5}$

Diagnosis dapat ditegakkan berdasarkan anamnesis lengkap mencakup keluhan utama, perjalanan penyakit, faktor eksogen yang mempengaruhi, faktor pencetus, faktor predisposisi penyakit, dan riwayat penyakit. Pemeriksaan fisik pada lokasi kulit dengan skuamanya juga harus diperhatikan. Pada kasus yang sulit didiagnosis atau sulit dibedakan dengan penyakit lain mungkin diperlukan pemeriksaan histopatologis. ${ }^{6}$

Pemberian terapi pada dermatitis seboroik harus mencakup penatalaksanaan untuk mengurangi gatal, memperbaiki struktur fungsi kulit, mencegah faktor resiko dan pencetus berulang, dan mengurangi efek gangguan estetika. Pada daerah non skalp pada dewasa bisa digunakan kortikosteroid topikal maupun anti jamur untuk dermatitis seboroik yang ringan, sedangkan pada yang berat bisa dikombinasikan penggunaan kortikosteroid topikal,sistemik, dan anti jamur. Penggunaan kalsineurin inhibitor topikal juga disarankan jika pengobatan sebelumnya tidak mencapai target terapi. Pada daerah kulit kepala bisa digunakan sampo antijamur yang dihentikan secara bertahap sampai remisi, jika tidak ada perbaikan bisa digunakan kombinasi dengan kortikosteroid topikal potensi lemah hingga kuat selama 2 minggu hingga 1 bulan. Anti jamur sistemik mungkin diperlukan jika berulang kembali. ${ }^{7,8,9}$

Untuk bayi, penggunaan emolien seperti petroleum jeli dan minyak zaitun efektif untuk pelepasan skuama kulit. Beberapa penelitian juga menunjukkan hasil pada penggunaan ketoconazol topikal $1 \%-2 \%$ yang digunakan dua kali sehari selama dua minggu. Sedangkan untuk sampo sampai saat ini belum direkomendasikan pada anak-anak usia dibawah 2 tahun. $^{7}$

\section{METODE}

Penelitian ini menggunakan metode deskriptif retrospektif dengan menggunakan catatan rekam medik pasien dermatitis seboroik yang tercatat di Poliklinik Kulit dan Kelamin serta Instalasi Rekam Medik RSUD Wangaya Denpasar periode 1 Oktober 2017- 1 Oktober 2017. Penelitian ini telah disetujui oleh komite medik RSUD Wangaya dengan nomer 070/2439/RSUDW. Populasi meliputi seluruh kasus yang tercatat menderita penyakit kulit di Poliklinik RSUD Wangaya periode Oktober 2017-Oktober 2018 dan sampel penelitian yaitu seluruh kasus yang tercatat menderita dermatitis seboroik. Variabel penelitian yaitu jumlah kasus, kelompk umur, jenis kelamin, pekerjaan, lokasi, dan jenis pengobatan.

\section{HASIL}

Jumlah pasien dermatitis seboroik adalah sebanyak pasien 67 dari 2931 pasien (2,3\%). Dermatitis seboroik tercatat terbanyak pada laki-laki dengan jumlah 43 pasien $(64,2 \%)$, usia terbanyak ditemui pada kelompok usia dewasa ( $\geq 35$ tahun) yaitu 52 pasien $(77,6 \%)$. Lokasi tersering penyakit ini adalah di daerah wajah sebanyak 36 pasien $(53,7 \%)$ dengan terapi yang paling sering digunakan berupa kortikosteroid topikal $(64,2 \%)$.

\section{DISKUSI}

Pada penelitian didapatkan jumlah pasien yang berobat ke poliklinik kulit dan kelamin RSUD Wangaya Denpasar periode Oktober 2017 sampai Oktober 2018 sebanyak 67 pasien (2,3\%) dari 2931 kunjungan total. 
Tabel 1. Profil penderita dermatitis seboroik berdasarkan jenis kelamin

\begin{tabular}{ccc}
\hline Jenis kelamin & Jumlah & Persentase (\%) \\
\hline Laki-laki & 43 & 64,2 \\
Wanita & 24 & 35,8 \\
Jumlah & 67 & 100 \\
\hline
\end{tabular}

Tabel 2. Profil penderita dermatitis seboroik berdasarkan kelompok usia

\begin{tabular}{lcc}
\hline \multicolumn{1}{c}{ Kelompok usia (tahun) } & Jumlah & Persentase (\%) \\
\hline Balita (0-5 tahun) & 9 & 13,4 \\
Anak-anak (5-11 tahun) & 2 & 3 \\
Remaja (12-25 tahun) & 4 & 6 \\
Dewasa ( $\geq 35$ tahun) & 52 & 77,6 \\
Jumlah & 67 & 100 \\
\hline
\end{tabular}

Tabel 3. Klasifikasi berdasarkan lokasi daerah yang terkena

\begin{tabular}{lcc}
\hline \multicolumn{1}{c}{ Lokasi } & Jumlah & Persentase \\
\hline Wajah & 36 & 53,7 \\
Badan & 20 & 29,9 \\
Lain-lain & 11 & 16,4 \\
Jumlah & 67 & 100 \\
\hline
\end{tabular}

Tabel 4. Profil penderita dermatitis seboroik berdasarkan pengobatan (kortikosteroid dan kortikosteroid + anti jamur)

\begin{tabular}{lcc}
\hline \multicolumn{1}{c}{ Pengobatan } & Jumlah & Persentase (\%) \\
\hline Kortikosteroid & 41 & $61,2 \%$ \\
Kortikosteroid dan Anti jamur & 26 & $38,8 \%$ \\
Jumlah & 67 & $100 \%$ \\
\hline
\end{tabular}

Tabel 5. Profil penderita dermatitis seboroik berdasarkan pengobatan kortikosteroid (kortikosteroid topikal dan kortikosteroid kombinasi oral + topikal)

\begin{tabular}{lcc}
\hline \multicolumn{1}{c}{ Pengobatan } & Jumlah & Persentase (\%) \\
\hline Kortikosteroid topikal & 43 & $64,2 \%$ \\
Kortikosteroid oral + topikal & 24 & $35,8 \%$ \\
Jumlah & 67 & $100 \%$ \\
\hline
\end{tabular}

Pada tabel pertama, menunjukkan bahwa sebanyak $64,2 \%$ pasien laki-laki mengalami dermatitis seboroik dibandingkan dengan wanita yaitu $35,8 \%$. Aktivitas kelenjar sebasea yang mempengaruhi ekskresi dari sebum lebih meningkat pada laki-laki karena adanya pengaruh dari hormon androgen terutama hormon testosteron. Oleh karena itu, penyakit yang memiliki predisposisi di kelenjar sebasea ini seringkali didapati pada lakilaki. ${ }^{1}$

Pada tabel kedua, didapatkan hasil bahwa kelompok usia dewasa ( $\geq 35$ tahun) lebih sering mengalami dermatitis seboroik yaitu 77,6\%. Adanya faktor-faktor seperti emosional, riwayat penyakit sebelumnya, kelelahan yang menyebabkan imunitas menurun akan mempengaruhi sekresi berlebih pada kelenjar sebasea dan mengakibatkan kolonisasi fungal lebih mudah untuk berkembangbiak. ${ }^{910}$ Diikuti 13,4\% oleh kelompok usia balita karena pembentukan kelenjar sebasea yang belum sempurna, disusul 6\% dari usia remaja dimana aktivitas dengan perubahan hormonal saat pubertas turut berperan mempengaruhi ekskresi kelenjar sebasea. Usia anak-anak juga menyumbang 3\% dari keseluruhan total pasien.

Pada tabel ketiga, lokasi yang sering ditemui pada dermatitis seboroik adalah daerah wajah sebanyak 53,7\%, seperti yang diketahui daerah dengan folikel sebasea memproduksi sebum terbanyak dari lokasi tubuh lainnya. ${ }^{9}$ Predileksi lain umumnya di lipatan tubuh terutama aksila dan paha, dada dan punggung yaitu $29,9 \%$.

Pada tabel terakhir, terapi tersering yang digunakan untuk pengobatan dermatitis seboroik adalah kortikosteroid sebanyak $61,2 \%$ disusul $38,8 \%$ menggunakan terapi kombinasi kortikosteroid dengan anti jamur. Anti inflamasi bisa digunakan topikalmaupun oral.Padadermatitisseboroikderajat ringan seringkali digunakan kortikosteroid topikal, sedangkan pada yang lebih berat diterapi dengan kortikosteroid oral maupun dengan penambahan agen anti fungal. Kortikosteroid baik topikal maupun oral berguna untuk mengurangi inflamasi yaitu eritema dan sebagai agen vasokonstriktor. Kortikosteroid terbagi atas potensi lemah, sedang, dan kuat. Untuk terapi pilihan di poliklinik kulit dan kelamin didapatkan betametason, mometason, dan deksosimetason sering digunakan pada dewasa. Sedangkan untuk usia anak-anak sering dijumpai penggunaan hidrokortison. Untuk penggunaan anti fungal sendiri, ketokonazol topikal dan oral masih menjadi pilihan tersering karena keefektifannya. ${ }^{1,8,9}$

Pada penelitian ini tidak didapatkan data mengenai pola makan (diet) dari pasien dengan dermatitis seboroik dimana menurut studi yang dilakukan oleh Sanders dkk. (2019) terdapat hubungan yang signifikan antara pola makan dengan kejadian dermatitis seboroik. Diharapkan pada penelitian selanjutnya diteliti variabel lain yang belum diteliti agar menjadi bahan pembelajaran bagi tenaga medis yang menemukan pasien dengan dermatitis seboroik. ${ }^{11}$

Pada penelitian ini penulis pertama bertindak sebagai corresponding author dan penulis kedua sebagai supervisor dalam penulisan penelitian ini. Tidak terdapat penggalangan dana apapun atau hibah yang diberikan oleh pihak manapun dalam pengerjaan penelitian ini. 


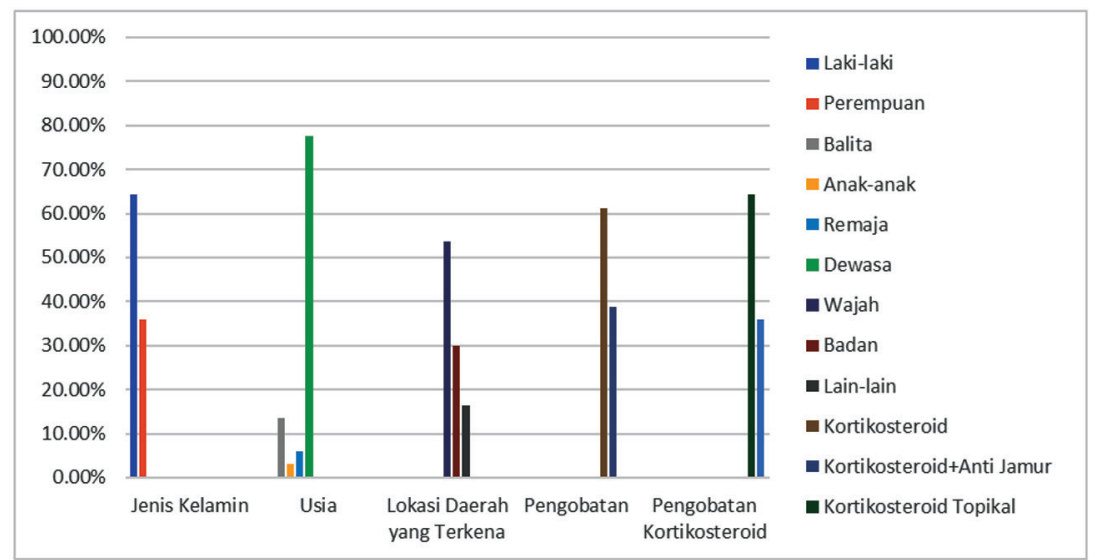

Gambar 1. Profil dermatitis seboroik pada pasien di Poliklinik Rawat Jalan Kulit dan Kelamin RSUD Wangaya Denpasar periode Oktober 2017-Oktober 2018

\section{SIMPULAN}

Dari penelitian retrospektif mengenai profil penyakit dermatitis seboroik di Poliklinik Kulit dan Kelamin RSUD Wangaya Denpasar periode Oktober 2017 hingga Oktober 2018 tercatat jumlah pasien dermatitis seboroik adalah 67 pasien $(2,3 \%)$. Dermatitis seboroik banyak ditemui pada laki-laki sebanyak $64,2 \%$ dengan usia terbanyak dewasa ( $\geq 35$ tahun) yaitu $77,6 \%$. Lokasi tersering pada penyakit ini adalah di daerah, dan pada penelitian ini terapi yang terbanyak digunakan adalah wajah $(53,7 \%)$ dengan terapi yang paling sering digunakan berupa kortikosteroid $(61,2 \%)$ terutama agen topikal $(64,2 \%)$.

Penyakit ini merupakan penyakit inflamasi kronis yang tidak membahayakan nyawa namun memiliki angka kejadian yang cukup tinggi baik pada dewasa maupun pada usia bayi. Penyebab dermatitis seboroik meliputi berbagai faktor yang mempengaruhi etiopatogenesisnya oleh karena itu diperlukan penegakan diagnosis mulai anamnesis, pemeriksaan fisik, maupun secara histopatologis di daerah predileksi penyakit ini. Pilihan terapi yang tepat akan mencegah rekurensi dan memperbaiki struktur fungsi kulit kembali.

\section{DAFTAR PUSTAKA}

1. Widaty Sandra, et al. Pedoman Nasional Pelayanan Kedokteran Tata Laksana Dermatitis Seboroik. Perhimpunan Dokter Spesialis Kulit dan Kelamin Indonesia, 2018:1.

2. Manuaba Citra, Puspawati Ni Made Dwi. Profil Penyakit Dermatitis Seboroik Pada Pasien di Poliklinik Rawat Jalan RSUP Sanglah Denpasar Bali tahun 2013-2015.

3. Borda LJ, Wikramanayake TC. Seborrheic Dermatitis and Dandruff: A comprehensive review. Journal of Clinical and Investigative Dermatology. December 2015;3(2):1-10.

4. Cheong Wai Kwong, et al. Treatment of Seborrhoeic Dermatitis in Asia: A Consensus Guide. Skin Appendage Disorders, November 2015;1:187-196.

5. Argir Argirov, ilko Bakardzhiev. New Insight into the Ethiopathogenesis of Seborrheic Dermatitis. Clinical Research in Dermatology: Open Access, January 2017;4(1):1-5.

6. Hajar Sitti. Manifestasi Klinis Dermatitis Seboroik pada Anak. Jurnal Kedokteran Syiah Kuala. Desember 2015;15(3):175-178.

7. Clark Gary W, Pope Sara M, Jaboori Khalid A. Diagnosis and Treatment of Seborrheic Dermatitis. American Family Physician. February 2015;91(3):185-190.

8. Dessinioti C, Katsambas A. Seborrheic dermatitis: Etiology, risk factors, and treatments: Facts and controversies. Clinics in dermatology. 2013 Jul 1;31(4):343-51.

9. Peyri J, Lleonart M. Clinical and therapeutic profile and quality of life of patients with seborrheic dermatitis. Actas Dermo-Sifiliográficas (English Edition). 2007 Jan 1;98(7):476-82.

10. Laswati Putra H, Alex Pangkahila J. Estrogen Receptors of Hairs Blacks and Whites. Bali Medical Journal. 2014;3(3):133-6.

11. Sanders MG, Pardo LM, Ginger RS, Kiefte-de Jong JC, Nijsten T. Association between diet and seborrheic dermatitis: A cross-sectional study. Journal of Investigative Dermatology. 2019 Jan 1;139(1):108-14.

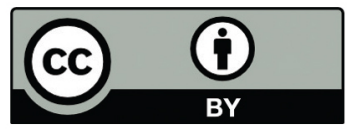

This work is licensed under a Creative Commons Attribution 